\begin{tabular}{|c|l|}
\hline Title & $\begin{array}{l}\text { Effects of Water Polluted by Oil on A quatic A nimals : II . n-paraffins, aromatic hydrocarbons and crude oil } \\
\text { concentration on taint in scall lop (Pecten yessoensis) }\end{array}$ \\
\hline Author(s) & MOTOHIRO, Terushige; ISEY A, Zensuke \\
\hline Citation & 北海道大學水産學部研究彙報, 26(4), 367-371 \\
\hline Issue Date & 1976-03 \\
\hline Doc URL & http://hdl.handle.net/2115/23575 \\
\hline Type & bulletin (article) \\
\hline File Information & 26(4)_P367-371.pdf \\
\hline
\end{tabular}

Instructions for use 
Bull. Fac. Fish. Hokkaido Univ.

26(4), 367-362. 1976.

\title{
Effects of Water Polluted by Oil on Aquatic Animals \\ II. n-paraffins, aromatic hydrocarbons and crude oil concentration on taint in scallop (Pecten yessoensis)
}

\author{
Terushige МотонIRo* and Zensuke IsEYA*
}

\begin{abstract}
Taints in scallop adduotor muscle were examined organoleptically to assess threshold concentration of n-paraffins, aromatic hydrocarbons, and crude oil. A test by tasting was found to be sensitive in reminiscence of the taints. $n$ Tetradecane and/or n-hexadecane was not found to cause the taint at $0.3 \mathrm{mg} / \mathrm{g}$. n-Paraffins are considered less important in causing taint than are crude oil, xylene, toluene, and mixtures of hydrocarbons which cause the taints at $0.1-$ $0.2 \mathrm{mg} / \mathrm{g}$.
\end{abstract}

Although marine plants and animals can survive in an environment polluted by petroleum oil or phenols at low levels, they are often tained by the pollutants to some extent. If the taint is such that they are no longer marketable, severe economic losses are suffered by fishermen and the fisheries industry.

The first fish reported as tainted was caught in 1953 in Yokkaichi Harbour, adjacent to which there are many petroleum refineries. Since that time, a considerable number of fish has been reported to be tainted in the waters around Japan.1) Hawkes ${ }^{2}$ ) stated that each and every one of quahog (Mercenaria mercenaria) in Narragansett Bay, Rhode Island had a taste and odour which would make the strongest stomach turn. Tainting of European mussel beds with oil has also caused serious economic problems²).

Ogata et al.3) have shown that taints can be caused by toluene. Nitta) found in laboratory experiments that fish can become tainted in concentrations of oil of $0.01 \mathrm{ppm}$ in water and $0.2 \%$ (by ether extraction) in bottom muds. The oily taint was obvious after 20 hours of exposure. It was further observed that fish would not avoid water masses polluted by oil. Yoshida et al. ${ }^{5}$ ) found that oily tainted eel contained saturated and unsaturated paraffins, aromatic hydrocarbons and thiophenes. $\mathrm{C}_{11}-\mathrm{C}_{22}$ n-paraffins, 5-ethyltridecane, and 8-propylpentadecane were isolated and chemically identified from brown trout (Salmo trutta $L$.) caught eleven days after a spillage of diesel fuel oil had occurred in their environment ${ }^{6}$ ). The composition of a volatile extract from mullet (Mugil cephalus) possessing a kerosene taint has been shown unequivocally to be $n$ tetradecane, naphthalene, 2-methylnaphthalene, and 1-methylnaphthalene, and tentatively methylisopropylbenzene, 3-(2-methylphenyl)pentane, 2,6-dimethyl-

* Training Factory of Food Engineering, Faculty of Fisheries, Hokkaido University (北海道大学水産学部食品製造実習工場) 
Bull. Fac. Fish. Hokkaido Univ. 26(4), 1976.

1,2,3,4-tetrahydronaphthalene and 2,3-dimethyl-1,2,3,4-tetrahydronaphthalene by gas chromatography and spectal analyses ${ }^{78)}$. Kaneda and Yasumoto ${ }^{9}$ ) found that oily taint fish contained $\mathrm{C}_{9}-\mathrm{C}_{11}$ hydrocarbons, high levels of alkylbenzene and olefins, and a trace amount of compounds containing sulphur. Few papers, however, have described threshold concentrations of the causative compounds of taints in fish flesh.

The present paper reports threshold concentrations of $n$-paraffins, aromatic hydrocarbons, and crude oil in tainted scallop (Pecten yessoensis) adductor muscle by organoleptic testing.

\section{Experimental}

\section{Material and samples}

The scallop (Pecten yessoensis) were caught in the waters near Hakodate City by a local commercial fisherman, and approximately $5 \mathrm{~kg}$ of 3-4 year shellfish were brought to the laboratory. After being shelled, adductor muscle was ground in a mortar to which starch was always added at $10 \%$ level (w/w). A small quantity of the slurry was checked for taint by tasting the cooked paste, and the remainder was mixed with hydrocarbons for organoleptic tests.

The hydrocarbons added to the slurry were (1) n-tetradecane, n-hexadecane, toluene, and xylene, (2) equal volume mixture of n-tetradecane, n-hexadecane, n-heptadecane, toluene and xylene, and (3) Arabian crude oil. The concentrations of the hydrocarbons in the slurry were $0,10,50,100,200$, and $300 \mathrm{ppm}$. The slurry containing hydrocarbon was divided into masses weighing $50 \mathrm{~g}$, each of which was pressed into a $20 \times 50 \mathrm{~mm}$ petri dish, cooked at $80-85^{\circ} \mathrm{C}$ for $15 \mathrm{~min}$., and cooled at room temperature.

\section{Organoleptic tests}

Up to two sets of 5 or 6 samples with different concentrations of hydrocarbons were served at any one time to 5-6 experienced tasters. The quarternary runs were made by the method of multiple comparison. After smelling and tasting 1.0 $\mathrm{g}$ of each sample, marking was made on a 1-5 hedonic (personal preference) scale, which was based on the following standards in comparison with the control sample: 1. Not tainted, 2. Slightly tainted, 3. A little tainted, 4. Obviously tainted, 5. Markedly tainted.

\section{Results and Discussion}

Table 1 shows analytical data of variance on an ability of distinction by panels for oily smell and taste with the samples containing 10-300 ppm crude oil.

It was found that there were significant differences in the judgement of oily smell by the two of six tasters, if comparison was made with variance ratios and the F-distribution value (3.26) at $95 \%$ confidence coefficient level. However, if it was made at $99 \%$ confidence coefficient level, only one of the six differences was 
Mотонтro \& IsEYA: Oil pollution II. Taint in scallop

Table 1. Analytical data of variance on ability of distinction by panels.

\begin{tabular}{|c|c|c|c|c|c|c|}
\hline \multirow{3}{*}{$\begin{array}{c}\text { Panels } \\
\text { No. }\end{array}$} & \multicolumn{3}{|c|}{ Oily taste } & \multicolumn{3}{|c|}{ Oily smell } \\
\hline & \multirow[b]{2}{*}{$\begin{array}{l}\text { Variance } \\
\text { ratios }\end{array}$} & \multicolumn{2}{|c|}{ F-distribution values } & \multirow[b]{2}{*}{$\begin{array}{c}\text { Variance } \\
\text { ratios }\end{array}$} & \multicolumn{2}{|c|}{ F-distribution values } \\
\hline & & $\begin{array}{c}1 \% \\
(99 \% \text { confidence } \\
\text { coefficient })\end{array}$ & $\begin{array}{c}5 \% \\
(95 \% \text { confidence } \\
\text { coefficient })\end{array}$ & & \begin{tabular}{|c|}
$1 \%$ \\
$(99 \%$ confidence \\
coefficient $)$
\end{tabular} & $\begin{array}{c}5 \% \\
(95 \% \text { confidence } \\
\text { coefficient) }\end{array}$ \\
\hline 1 & 10.18 & 5. 41 & 3.26 & 1.31 & 5.41 & 3.26 \\
\hline 2 & 10.62 & 5.41 & 3.26 & 3.46 & 5.41 & 3.26 \\
\hline 3 & 20.46 & 5.41 & 3.26 & 7.33 & 5.41 & 3.26 \\
\hline 4 & 13.18 & 5.41 & 3. 26 & 1.00 & 5.41 & 3.26 \\
\hline $\mathbf{5}$ & 2.28 & 5.41 & 3.26 & 1.00 & 5.41 & 3.26 \\
\hline 6 & 18.33 & 5.41 & 3.26 & 2.14 & 5.41 & 3.26 \\
\hline
\end{tabular}

significent. As to the oily taste, the five of six differences between variance ratios and the F-distribution values (3.26 and 5.41) were significant both at $95 \%$ and $99 \%$ confidence coefficient levels. This fact suggests that tasting is thought to be a sensitive test to find accurately crude oil taint in scallop.

Table 2 shows the statistical data on oily taint by organoleptic test. In the group with crude oil, the variance ratio among the samples was 54.95. This value was higher than $\mathrm{F}$-distribution value $(3.50)$ at $99 \%$ confidence coefficient level, and there was highly significant difference among the samples with and without crude oil. While the variance ratio among the panels was 21.23 , and was also higher than the F-distribution value (3.18) at $99 \%$ confidence coefficient level. Thus, it is obvious that the strength of oily taint to be found varies with different panels. From this fact, the groups with and without crude oil are thought to be distinguishable by tasting test.

In the group with equal volume mixture of $n$-tetradecane, $n$-hexadecane, nheptadecane, toluene, and xylene, the variance ratios among the samples and the panels were 12.09 and 4.98 , respectively. These values were higher than the F-distribution value (3.51) at $99 \%$ confidence coefficient level, and significant differences were found among the samples with and without mixture of hydrocarbons and among the scores of the panels. This result was similar to that of the group with crude oil.

In the samples to which $n$-tetradecane and $n$-hexadecane were added separately, the variance ratios among the samples were lower than the F-distribution values (3.17 and 2.29 ) at $99 \%$ and $95 \%$ confidence coefficient levels, and any significant difference was not found among the samples. While the separate samples contained toluene and xylene gave the results that the variance ratios among the samples were 14.14 and 24.87, and both of which were higher than the F-distribution values (3.17-3.18 and $2.29-2.30)$ at $99 \%$ and $95 \%$ confidence coefficient levels, respectively. This fact indicates that the aromatic hydrocarbons would be more clearly detectable organoleptically than n-paraffins in scallop.

When the results obtained by panels who tasted $0.1 \mathrm{mg} / \mathrm{g}$ and $0.2 \mathrm{mg} / \mathrm{g}$ of crude oil in the samples were calculated statistically the standard deviations 
Bull. Fac. Fish. Hokkaido Univ. 26(4), 1976.

Table 2. Statistical data on oily taint by organoleptic test.

\begin{tabular}{|c|c|c|c|c|c|c|}
\hline \multirow{3}{*}{ Groups } & \multirow{2}{*}{\multicolumn{2}{|c|}{$\begin{array}{l}\text { Variance } \\
\text { ratios }\end{array}$}} & \multicolumn{4}{|c|}{ F-distribution values } \\
\hline & & & \multicolumn{2}{|c|}{$\begin{array}{c}1 \% \\
\text { (99\% confidence } \\
\text { coefficient) }\end{array}$} & \multicolumn{2}{|c|}{$\begin{array}{c}5 \% \\
\text { (95\% confidence } \\
\text { coefficient) }\end{array}$} \\
\hline & Samples & Panels & Samples & Panels & Samples & Panels \\
\hline Crude Oil & 54.95 & 21.23 & 3.50 & 3.18 & 2.45 & 2.30 \\
\hline Mixed Hydrocarbon & 12.09 & 4.98 & 3. 51 & 3.61 & 2.46 & 2.46 \\
\hline n-Tetradecane & - & 1.92 & 3.17 & - & 2.29 & - \\
\hline n-Hexadecane & - & $一$ & 3.17 & 一 & 2.29 & - \\
\hline Toluene & 14.14 & 1.17 & 3.17 & - & 2.29 & - \\
\hline Xylene & 24.87 & 1.46 & 3.17 & 3. 50 & 2. 30 & 2.45 \\
\hline
\end{tabular}

Table 3. Threshold concentrations of hydrocarbons and crude oil in tainted scallop adductor muscle.

\begin{tabular}{|c|c|c|c|c|c|c|c|c|c|}
\hline \multirow{2}{*}{\multicolumn{2}{|c|}{ Concentration }} & (ppm) & 0 & 10 & 30 & 50 & 100 & 200 & 300 \\
\hline & & $(\mathrm{mg} / \mathrm{g})$ & 0 & 0.01 & 0.03 & 0.05 & 0.10 & 0.20 & 0.30 \\
\hline \multirow{3}{*}{$\begin{array}{l}\text { Crude } \\
\text { Oil }\end{array}$} & \multicolumn{2}{|l|}{ Mean } & 2.50 & 2.08 & - & 3.00 & 4.58 & 5. 50 & - \\
\hline & \multicolumn{2}{|l|}{$\begin{array}{l}\text { Standard } \\
\text { deviations }\end{array}$} & & - & - & 0.50 & 2.08 & 3.00 & \\
\hline & $\begin{array}{l}\text { Least } \\
\text { significant } \\
\text { differences }\end{array}$ & $\begin{array}{l}5 \% \\
1 \%\end{array}$ & $\begin{array}{l}1.36 \\
1.79\end{array}$ & $\begin{array}{l}1.36 \\
1.79\end{array}$ & $\begin{array}{l}1.36 \\
1.79\end{array}$ & $\begin{array}{l}1.36 \\
1.79\end{array}$ & $\begin{array}{l}1.36 \\
1.79\end{array}$ & $\begin{array}{l}1.36 \\
1.79\end{array}$ & \\
\hline \multirow{3}{*}{$\begin{array}{l}\text { Mixed } \\
\text { Hydrocarbon }\end{array}$} & \multicolumn{2}{|l|}{ Mean } & 1.50 & 1.60 & - & 1.70 & 2. 50 & 3.90 & - \\
\hline & \multicolumn{2}{|l|}{$\begin{array}{l}\text { Standard } \\
\text { deviations }\end{array}$} & & 0.10 & - & 0.20 & 1.00 & 2. 40 & \\
\hline & $\begin{array}{l}\text { Least } \\
\text { significant } \\
\text { differences }\end{array}$ & $\begin{array}{l}5 \% \\
1 \%\end{array}$ & $\begin{array}{l}1.64 \\
2.17\end{array}$ & $\begin{array}{l}1.64 \\
2.17\end{array}$ & $\begin{array}{l}1.64 \\
2.17\end{array}$ & $\begin{array}{l}1.64 \\
8.17\end{array}$ & $\begin{array}{l}1.64 \\
2.17\end{array}$ & $\begin{array}{l}1.64 \\
2.17\end{array}$ & \\
\hline \multirow{3}{*}{ Toluene } & \multicolumn{2}{|l|}{ Mean } & 1.67 & 1.42 & 1.75 & 2.00 & 2.83 & 3.75 & \\
\hline & \multicolumn{2}{|l|}{$\begin{array}{l}\text { Standard } \\
\text { deviations }\end{array}$} & & 一 & 0.08 & 0.33 & 1.15 & 2.08 & - \\
\hline & $\begin{array}{l}\text { Least } \\
\text { significant } \\
\text { differences }\end{array}$ & $\begin{array}{l}5 \% \\
1 \%\end{array}$ & $\begin{array}{l}1.32 \\
1.75\end{array}$ & $\begin{array}{l}1.32 \\
1.75\end{array}$ & $\begin{array}{l}1.32 \\
1.75\end{array}$ & $\begin{array}{l}1.32 \\
1.75\end{array}$ & $\begin{array}{l}1.32 \\
1.75\end{array}$ & $\begin{array}{l}1.32 \\
1.75\end{array}$ & . \\
\hline \multirow{3}{*}{ Xylene } & \multicolumn{2}{|l|}{ Mean } & 1.00 & 1.70 & - & 2.10 & 3.20 & 3.20 & 4.40 \\
\hline & \multicolumn{2}{|l|}{$\begin{array}{l}\text { Standard } \\
\text { deviations }\end{array}$} & & 0.70 & - & 1.10 & 2.20 & 2. 20 & 3.40 \\
\hline & $\begin{array}{l}\text { Least } \\
\text { significant } \\
\text { differences }\end{array}$ & $\begin{array}{l}5 \% \\
1 \%\end{array}$ & $\begin{array}{l}1.27 \\
1.68\end{array}$ & $\begin{array}{l}1.27 \\
1.68\end{array}$ & $\begin{array}{l}1.27 \\
1.68\end{array}$ & $\begin{array}{l}1.27 \\
1.68\end{array}$ & $\begin{array}{l}1.27 \\
1.68\end{array}$ & $\begin{array}{l}1.27 \\
1.68\end{array}$ & $\begin{array}{l}1.27 \\
1.68\end{array}$ \\
\hline
\end{tabular}


of mean values were 2.08 and 3.00 , respectively. These values were higher than that of the least significant difference (1.79) at $99 \%$ confidence coefficient level. This result suggests that the panels could detect the crude oil taints significantly at $0.1 \mathrm{mg} / \mathrm{g}$ of the oil concentration.

Using the group with the mixture of hydrocarbons, the standard deviation of the mean values was higher when the panels tasted the sample containing 0.2 $\mathrm{mg} / \mathrm{g}$ of hydrocarbons, but was lower when the panels tasted the sample containing $0.1 \mathrm{mg} / \mathrm{g}$ of hydrocarbons, than the value of the least significant difference at $99 \%$ confidence coefficient level. A similar result was obtained in the group with toluene. A tasting test gave positive results with $0.1 \mathrm{mg}$ of xylene in $1 \mathrm{~g}$ of sample, but negative with $0.05 \mathrm{mg}$ of xylene.

As summarized in Table 3, it seems to be difficult to detect organoleptically the taint in scallop with $\mathrm{n}$-tetradecane or $\mathrm{n}$-hexadecane concentration at $0.3 \mathrm{mg} / \mathrm{g}$. The taint, however, can be found in scallop to which either $0.1 \mathrm{mg} / \mathrm{g}$ of xylene and crude oil or $0.2 \mathrm{mg} / \mathrm{g}$ of mixture hydrocarbons and toluene was added, respectively. Therefore, it is concluded that n-paraffins are not important as factors influencing the flavour of scallop polluted by petroleum oil.

Mackie et al.6) have obtained a crude assessment of the hydrocarbon concentration by measuring the relative intensity of the 8-propyl pentadecane peak in a given volume of oil and the hydrocarbon from the fish polluted by diesel oil and the figure obtained for the wet weight of fish was $300 \mathrm{ppm}$. The finding in the present study in which $200 \mathrm{ppm}$ of the mixture of hydrocarbons could cause tainting in scallop may give an indication of the hydrocarbon concentration in brown trout polluted by diesel oil.

The authors are indebted to Dr. R.M. Love, Torry Research Station, Aberdeen, Scotland, for helpful reviews of the manuscript.

\section{References}

1) Mie Prefecture. (1964). Special report for the research on taint of fish. Rept. Publ. Nur., Mie Pref. 23, 1-30. (In Japanese).

2) Katz, M. (1971). Water and water pollution handbook: Effect of pollution upon aquatic life. 449p. Marcel Dekker, Inc., New York.

3) Ogata, M. and Miyake, Y. (1970). Offensive-odor substance in fish in the sea along petrochemical industries. Japan. J. Publ. Health. 17, 1125-1129.

4) Nitta, T. (1967). Contamination of fish and shellfish by factory wastes. Ibid. 7, 123132. (In Japanese).

5) Yoshida, K. and Uezumi, N. (1961). On the tainted fish in the waters in petrochemical industries. Seikatsu-Eisei. 1, 1-11. (In Japanese).

6) Mackie, P.R., MeGill, A.S. and Hardy, R. (1972). Diesel oil contamination of brown trout (Salmo trutta L.). Environ. Pollut. 3, 9-16.

7) Vale, G.L., Shidhu, G.S., Montgomery, W.A. and Johnson, A.R. (1970). Studies on a kerosene-like taint in mullet (Mugil cephalus). I. General nature of the taint. J. Sci. Fd Agric. 21, 429-432.

8) Shipton, J., Last, J.H., Murry, K.E. and Vale, G.L. (1970). Ditto. II. Chemical nature of the volatile constituents. Ibid. $21,433-436$.

9) Kaneda, N. and Yasumoto, T. (1974). A study on the compositions in oil wastes for taint of fish. Rept. Appl. Res., Agency Fishery. 1-13. (In Japanese). 